\title{
Proceeding
}

Supplementary Issue: Spring Conferences of Sports Science. First International Conference in Iraq on Sport for Peace, 4 April 2019. Baghdad Science Institute, Baghdad, Iraq.

\section{The effect of special force training on the development of biomechanical variables for running raising awareness during the performance on the jumping table}

\author{
ZINAH ABDUL SALAM ABDUL RAZZAQ ${ }^{1}$, AHMED SEBEAATEA ALMUJAMAY², HAMEED AHMED \\ MOHAMMED ALMOJAMAY3 \\ ${ }^{1}$ College of Physical Education and Sport Sciences for Women, University of Baghdad, Iraq \\ ${ }^{2}$ College of Physical Education and Sports Sciences, University of Baghdad, Iraq \\ ${ }^{3}$ College of Physical Education and Sport Sciences, University of Tikrit, Iraq
}

\begin{abstract}
The strength training greatly affect the speed of motor performance, especially the stage of the performance of the raft and the upgrade, where the player needs to force the moment of elevation to pass the jump platform, and must be based on these exercises based on real indicators based on scientific results to know the nature of this power of the player and its impact on The length of the step of the glove during the moment of elevation to pass the plate of advancement, through sweating on the nature of the power of the initial hula the last three steps and hitting the plate of the advancement can be used (Foot scan) to determine this strength and corrected foot position and areas of pressure taken to develop this Thus enabling the effect of mechanical variables and achieving good performance of these skills. The researcher was keen to measure these forces through the use of a foot scanner and the extraction of kinematic variables for the skill of the Arab jump, especially the rough stage and the advancement through video photography and kinetic analysis and the preparation of special exercises to develop these variables in order to solve This problem was imposed by the researcher. There are no statistically significant differences between the tribal and remote tests in the indices of the foot scan and the kinetics and the strength of the Tsukahara skill of the Round Off Back tuck (Tsukahara) on the jumping platform. The research on the sample of the research on the players
\end{abstract}

\footnotetext{
Corresponding author. College of Physical Education and Sport Sciences for Women, University of Baghdad, Iraq.

E-mail: zena@copew.uobghdad.edu.iq

Supplementary Issue: Spring Conferences of Sports Science. First International Conference in Iraq on Sport for Peace, 4 April 2019. Baghdad Science Institute, Baghdad, Iraq.

JOURNAL OF HUMAN SPORT \& EXERCISE ISSN 1988-5202

(c) Faculty of Education. University of Alicante

doi:10.14198/jhse.2019.14.Proc4.04
}

S458 | 2019| Proc4 | VOLUME 14

C 2019 University of Alicante 
of the national junior team for the ages (11-13) years (6) players was extracted and the value of $(T)$ between the results of tribal and remote tests and concluded the researcher. The effectiveness of the exercises in the training curriculum in the improvement of the rounder and upgrade according to the indices (Foot scan) and kinetic in the performance of the round off back tuck (Tsukahara) on the jump platform, and worked to reduce the deviation of the foot from the real path of the approximate run, which helps the economy time and effort and reduce Distance and skill development. Keywords: Foot scanner; Approximate rotation; Elevated force; Elevation; Video filming.

\section{Cite this article as:}

Razzaq, Z.A.S.A., Almujamay, A.S., \& Almojamay, H.A.M. (2019). The effect of special force training on the development of biomechanical variables for running raising awareness during the performance on the jumping table. Journal of Human Sport and Exercise, 14(4proc), S458-S468. doi:https://doi.org/10.14198/ihse.2019.14.Proc4.04 


\section{INTRODUCTION}

The performance of the horse jumping device is characterized by a single sport movement, which makes it associated with the speed of speed, along with other characteristics such as moving speed, constant balance and special agility (Shehata,1992). Training should begin to develop strength and capacity at an early age in order to maximize the potential and completion of the skills required for the top competitions. It is essential for the gymnast player to possess enough explosive power in the lower limb muscles in order to perform many required jumping skills while maintaining body control (2-3). It is essential that players have advanced explosive energy in the lower and upper muscular system, especially for jumping and performing the heart (4-5-6). It is recognized that reaching the elite level of gymnastics requires high levels of strength, ability, flexibility, agility and intensive physical training and therefore must be started at an early age (7-8). The skilful performance of the horse jumping device is carried out in several consecutive technical stages. The success of each phase is a good indication of the success of the next stage in the overall skill performance. The stages of performance on the jumping horse can be summarized in "Approaching - Upgrading - First Flight Mastering and Paying - Second Flight - Landing"(Ford et al,2011), And these stages are interconnected and depends on the success of any stage on the success of the stage preceded by the stage of hitting the board of advancement on the success of the racer, the player needs to force the moment of the upgrade to cross the jump platform, as well as when landing on the rug, so must be built according to indicators Based on scientific results to know the strength of the player and the biomechanical variables of the first and second stage using the foot scan device, it helps in detecting the strength of the feet, the time of contact and the pressure exerted, and the extent of the use of these indicators AsaYeh in the development of strength training methods Balaatamd on Albayumkankih principles and to achieve good performance through the use of kinetic analysis according to the required motor performance through a number of exercises to develop the necessary strength and mention(Abd al-Khaliq,2005). Muscle strength is one of the most important physical and motor abilities that affect the level of performance in sports activities. Muscle strength is considered to be the most basic ability in all forms of sports activity, but its degree of existence varies according to each physical performance. Physical performance is always against different resistors (Dinyman,1998).

(1) of the basic skills that require high accuracy in performance, especially the stage of upgrading is the last stage affecting the body of the player to the ground, and then control is associated with the stage of upgrading in terms of positioning the feet in the right place And the amount of strength and speed necessary to achieve the highest rise and less time, so they need to develop strength training for these variables and develop them for the better.

Hence the importance of research by identifying the type of data and accuracy in the number of exercises to the special force to avoid error and imbalance in them and then upgrade the training process.

Therefore, the researcher believes that the performance achieved for young people does not achieve the ambition of the international championships because there are many problems related to performance and the instantaneous power given to the moment of upgrading the working muscles of the two men in order to create the appropriate conditions in the last three steps before hitting the board of elevation Which are key factors in the integration of acceleration and obtaining the highest acceleration of the body and not naming the last three steps before hitting the glove. This occurs by knowing some of the biochemical variables of the approximate run and upgrading and detecting the strengths and weaknesses of these Two phases through the exercise of power and speed to get to put the correct path of the motor body, to carry out dynamic movements difficult as show in figure (1). 


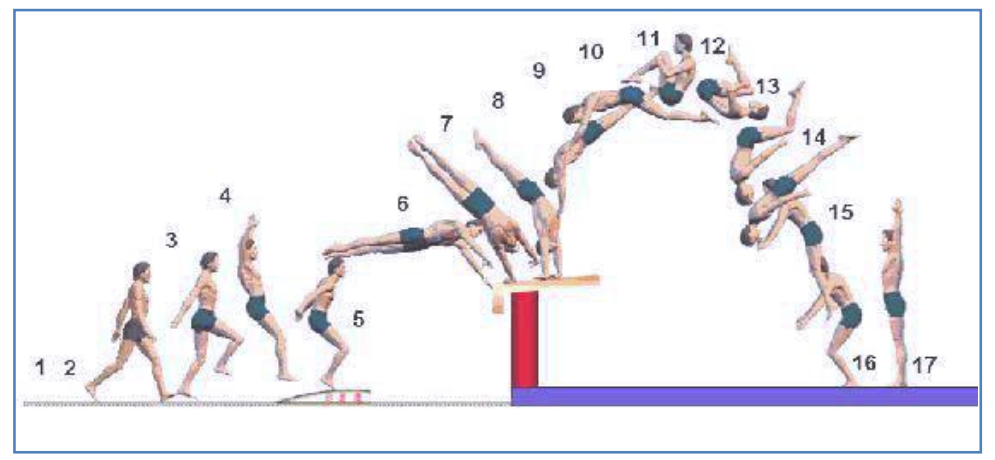

Figure 1. Round off Back tuck

\section{Research Goal}

The aim of this study was to determine the effect of special force training when added to the usual gymnastics training on performance variables during the Round off Back tuck Methodology.

\section{The sample subjects}

The research sample included the players of the national junior team with ages of (11-13) years and the number of (6) out of (7) players representing $71 \%$ of the community of origin and were chosen in a deliberate manner and the researcher used the style of one group. Morphological measurements were (mean \pm standard deviation: age) $11.67 \pm 0.82)$, Length (139.92 \pm 11.56$)$, mass (35.75 \pm 6.71$)$ training age (6.5 \pm 1.87 ) with participation in gymnastics competitions not less than three years. The participants in this study were all able to implement Round off Back tuck (Tsukahara).

\section{METHOD}

Before the application of the training program, the researcher relied on measuring the performance level and the biomechanical variables by imaging the performance of the device (Foot Scan) put the device foot scanner on the ground before the springboard to give a correct and accurate reading of the indicators to be measured and stands on the starting line and after the whistle The start starts off towards the jumping platform of the round-back tuck (Tsukahara). The data of each player (weight, age and foot size) was recorded in the computer attached to the foot scanner so that the device is ready to measure the force and the pressure exerted and angle of deflection of the foot and give the results directly after the attempt. The first cameras were placed on the side of the jumping platform $(8 \mathrm{~m})(11,30 \mathrm{~m})$ and height $(130 \mathrm{~cm})$. And then presented the performance of each player on four arbitrators to evaluate the performance was extracted indicators of the mechanic foot scanner for the members of the research sample was given three transformers per player was calculated best attempt (Bencke et al,2002).

Training program: The technical training of the technical performance of the research skill was developed Round off Back tuck (Tsukahara) on the jumping table of the research sample and the program began to be implemented on 19/4/2018 until 5/6/2018. The application of the exercises took 8 weeks (35) minutes in the main part to be a total of (24) training units using repetitive training in the main section of the training unit as shown in Table (1). Abu Alak mentioned that most of the variables resulting from Training usually takes place within (6-8) weeks, where a set of strength exercises has been selected in the appropriate curriculum For example, their physical abilities and these exercises are explosive power exercises and the strength of the speed by using vertical jumping exercises and horizontal jumps using a platform, barriers and stairs in both legs or exchange, and this is certainly the performance of the distance of the step of the glove and the correct angles(Bradshaw\&Rossignol,2004), as show in table (1). 
Table 1. Sample of training modules Period: Special preparation. Unit: 19, 20, 21 (Unit 7) Exercise time: 32 - 35 minutes Date $26,28,30 / 5 / 2018$

\begin{tabular}{|c|c|c|c|c|c|c|c|c|}
\hline$S$ & Exercises & Intensity & $\begin{array}{l}\text { Performance } \\
\text { Time }\end{array}$ & Repetition & $\begin{array}{l}\text { Rest } \\
\text { between } \\
\text { repetition }\end{array}$ & Aggregates & $\begin{array}{l}\text { Total } \\
\text { Time }\end{array}$ & $\begin{array}{l}\text { Comfort } \\
\text { groups }\end{array}$ \\
\hline 1 & $\begin{array}{l}\text { Jump between } \\
\text { the stairs with } \\
\text { the wearing of } \\
\text { gravity right foot } \\
\text { with the use of } \\
\text { rubber cord with } \\
\text { the help of a } \\
\text { colleague }\end{array}$ & $\% 85$ & $8 \mathrm{sec}$ & 4 & 24 & 2 & 3.2 & \multirow[b]{3}{*}{$\begin{array}{c}\text { Return } \\
\text { the } \\
\text { pulse to } \\
120 \\
\text { pulses }\end{array}$} \\
\hline 2 & $\begin{array}{l}\text { Running on the } \\
\text { stands at full } \\
\text { speed }\end{array}$ & - & $2 \mathrm{sec}$ & 5 & 6 & 2 & 1.2 & \\
\hline 3 & $\begin{array}{l}\text { (Stand - Cope } \\
\text { barriers) full } \\
\text { bend your knees } \\
\text { and then jump in } \\
\text { front of the } \\
\text { highest above } \\
\text { inhibitor and } \\
\text { landing feet } \\
\text { together and } \\
\text { then jump over } \\
\text { the mind and the } \\
\text { second landing } \\
\text { Backman } \\
\text { together }\end{array}$ & & $3 d$ & 4 & 40 & 2 & $3 d$ & \\
\hline 4 & $\begin{array}{l}\text { Jogging }(125 \mathrm{~m}) \\
\text { Arab action and } \\
\text { then jump on the } \\
\text { glove for the } \\
\text { work of aerobic } \\
\text { bacterium } \\
\text { summersault on } \\
\text { the platform } \\
\text { jumping }\end{array}$ & & $7 \mathrm{sec}$ & 5 & 21 & 2 & 3.9 & \\
\hline 5 & $\begin{array}{l}\text { Jogging strides } \\
\text { distance }(10 \mathrm{~m}) \\
\text { and the work of } \\
\text { the Arab air } \\
\text { jump are } \\
\text { preceded by my } \\
\text { heart on a }\end{array}$ & & $6 \mathrm{sec}$ & 5 & 18 & 2 & 3.4 & \\
\hline
\end{tabular}




\begin{tabular}{|c|c|c|c|c|c|c|c|}
\hline & $\begin{array}{l}\text { platform Mtkorh } \\
\text { jump }\end{array}$ & & & & & & \\
\hline 6 & $\begin{array}{l}\text { With the work } \\
\text { Dbna full } \\
\text { hearing Whistle } \\
\text { streaming is } \\
\text { accelerating }\end{array}$ & & $10 \mathrm{sec}$ & 5 & 30 & 2 & 5.6 \\
\hline 7 & $\begin{array}{l}\text { Place to run fast } \\
\text { with the lifting } \\
\text { knees high }\end{array}$ & & $3 \mathrm{sec}$ & 10 & 9 & 3 & 5.5 \\
\hline 8 & $\begin{array}{l}\text { Dbna with } \\
\text { jumping up with } \\
\text { the use of } \\
\text { weightlifting }\end{array}$ & $\% 85$ & $3 \mathrm{sec}$ & 10 & 9 & 2 & 3.7 \\
\hline 9 & $\begin{array}{l}\text { Take a step } \\
\text { forward with the } \\
\text { jump to make } \\
\text { the Arab jump } \\
\text { followed by an } \\
\text { airborne volcano } \\
\text { on the ground }\end{array}$ & & $3 \mathrm{sec}$ & 5 & 9 & 3 & 2.5 \\
\hline
\end{tabular}

After the end of the training program, the researcher conducted remote tests on the research sample on $6 / 6 / 2018$ in the hall of the training centre of the technical gymnasium Zayouna and used the same equipment and conditions and the manner in which the tribal test was carried out. Also, measurements of the Foot Scan and the biomechanical variables of skill Research and evaluate the technical performance of the skill (Jemni et al,2006).

\section{STATISTICAL METHODS}

SPSS (Paired-Samples T Test) was used for interrelated samples, Results and Discussion Results and discussion, as show in table (2).

Table 2. Shows the computational and standard deviations and the calculated value (T) of the Foot Scan indices between the tribal and remote tests of the research sample

\begin{tabular}{|c|c|c|c|c|c|}
\hline \multicolumn{2}{|c|}{$S$} & 1 & 2 & 3 & 4 \\
\hline \multicolumn{2}{|c|}{ variable } & Inflicted force & Pressure off & Deviation Angel & Contact time \\
\hline \multicolumn{2}{|c|}{ Measuring unit } & $\mathrm{Nt} / \mathrm{sec}$ & $\mathrm{Nt} / \mathrm{cm}^{2}$ & degree & sec \\
\hline \multirow{2}{*}{ Measuring unit } & $S$ & 935.9 & 48.9 & 20.15 & 0.31 \\
\hline & $\mathrm{h}$ & 202.7 & 6.99 & 3.68 & 0.04 \\
\hline \multirow{2}{*}{ The first test } & S & 1076.9 & 58.6 & 17.38 & 0.23 \\
\hline & $\mathrm{h}$ & 86.3 & 3.85 & 0.68 & 0.02 \\
\hline \multicolumn{2}{|l|}{ The first test } & 141 & 9.7 & 2.77 & 0.08 \\
\hline \multicolumn{2}{|l|}{ The last test } & 171.32 & 3.66 & 1.64 & 0.05 \\
\hline \multicolumn{2}{|l|}{ value } & 4.841 & 6.492 & 4.140 & 4000 \\
\hline
\end{tabular}


Table (1) shows that the calculated T values were significant in favour of the post-test. The researchers attributed the reason for this progress in the foot scanner indicators to the exercises that were used and the use of aids according to the performance, which had a positive and effective effect in the development of performance, Which is based on the use of the device (Foot Scan) and correction of the pressure areas of the foot through the exercises in jogging in the form of stability and halogen, which led to the development of physical abilities required by the player with the remarkable improvement in the Kinamatik variables of the two stages of rapprochement and upgrading and development with the development of strength To pay, which has an active role in improving the approximate stage sprint and upgrading with the relative decrease in its time(Kums et al,2005), which was developed and also hopscotch movements before upgrading an initial stage.

Dintiman notes that "special exercises that help in the development of muscle work in jogging and improve the speed of their steps and then the maximum speed less than (0.6 tha) and more (12). These exercises also have an effective effect in stimulating the central nervous system and in turn, he developed neurotransmitters and created a kind of counselling to stimulate positive muscle groups. (Dinyman,1998) As the force was used in a relatively shorter period of time, the effect of pushing the force was greater, as Saeb al-Ubaidi said. "When used for a short period, If in a long period of time (al-Obeidi et al,1991).

As for the variable pressure of the foot, the researcher attributed the reason for this improvement in the strength of the pressure attached to the foot is the result of corrective exercises, which applied some tools and aids to jump and the hurdle on the performance and also had a significant impact on the reaction (focus force at the moment of focus), improving the foot position at In the tribal test where the area on which the foot was based was large, this reflected a few values of the pressure force in these tests and improved foot position in the remote tests through the training of jogging, jumping and jumping Improve step and put the foot(Bradshaw et al,2014).

The angle of the deviation of the foot at the moment of striking the glove showed significant differences in favour of the post-test which adds distance to the horizontal distance that the player runs. The researcher attributes this development to corrective exercises for the position of the foot and to exercise. Approximate Rhythm Through these exercises you get the economy of distance and time to cut this distance (Bale \& Goodway ,1990).

Kurz points out that "the jogging methods make the muscles of the two men more consistent and responsive to muscular reflexes at moments of instantaneous force with the ground." These theories argue that the increased horizontal linear momentum resulting from rapid jogging with help changes the movement of the knee joint and Allows the movement of power in a streamlined and economical manner (Kurz,2001).

The researcher also attributed the emergence of significant differences between the tribal and remote testing in the time of the request by using special exercises that have a role in reducing the time of the request because it is based on the strength and speed, especially in the rough stage and the advancement of the fact that the player is doing a preliminary hull before the stage of evolution, The position of the saints, these exercises worked to overcome this slow and correct the position of the feet and focus on the instep contributes to reduce time, as show in table (3). 
Table 3. Reduce Time

\begin{tabular}{|c|c|c|c|c|c|c|c|c|c|}
\hline \multirow{2}{*}{$\begin{array}{l}\text { VALUE } \\
T^{*}\end{array}$} & \multirow{2}{*}{$\begin{array}{l}\text { THE } \\
\text { LAST } \\
\text { TEST }\end{array}$} & \multirow{2}{*}{$\begin{array}{l}\text { THE } \\
\text { FIRST } \\
\text { TEST }\end{array}$} & \multicolumn{2}{|c|}{$\begin{array}{c}\text { THE FIRST } \\
\text { TEST }\end{array}$} & \multicolumn{2}{|c|}{$\begin{array}{l}\text { MEASRUING } \\
\text { UNIT }\end{array}$} & \multirow{2}{*}{$\begin{array}{l}\text { MEASRUING } \\
\text { UNIT }\end{array}$} & \multirow[t]{2}{*}{ Variables } & \multirow[t]{2}{*}{$\mathbf{S}$} \\
\hline & & & $\mathrm{h}$ & $\mathbf{s}$ & $\mathrm{h}$ & $\mathbf{s}$ & & & \\
\hline 4.598 & 0.458 & 0.86 & 0.595 & 7.47 & 0.647 & 6.61 & $\mathrm{~m} / \mathrm{sec}$ & $\begin{array}{c}\text { The approximate } \\
\text { speed sprint (10 } \\
\text { m) }\end{array}$ & 1 \\
\hline 5.897 & 0.096 & 0.23 & 0.185 & 1.27 & 0.145 & 1.50 & $\mathrm{sec}$ & $\begin{array}{c}\text { The approximate } \\
\text { time of sprint (10 } \\
\text { m) }\end{array}$ & 2 \\
\hline 5.806 & 0.077 & 0.18 & 0.168 & 2.63 & 0.296 & 2.45 & $\mathrm{~m}$ & $\begin{array}{l}\text { Step Gauntlet } \\
\text { distance }\end{array}$ & 3 \\
\hline 3.333 & 0.039 & 0.05 & 0.026 & 0.76 & 0.053 & 0.81 & $\mathrm{sec}$ & $\begin{array}{l}\text { The reduce time } \\
\text { three-step time }\end{array}$ & 4 \\
\hline 5.905 & 1.245 & 3 & 1.5 & •63 & 2 & 60 & degree & $\begin{array}{l}\text { Starting body } \\
\text { angle }\end{array}$ & 5 \\
\hline 4.152 & 2.949 & 5 & 2.75 & 68 & 3 & 63 & & $\begin{array}{c}\text { Angle } \\
\text { advancement }\end{array}$ & 6 \\
\hline 4.098 & 0.695 & 1.16 & 0.329 & 11.41 & 0.539 & 10.25 & degree & the performance & 7 \\
\hline
\end{tabular}

It is clear from Table (3) that there are significant differences between the tests of tribal and remote biochemistry variables and technical performance. The researcher attributed that the exercises that were developed for the rapid running of $10 \mathrm{~m}-15 \mathrm{~m}$ led to adapt to this exercise helped develop the speed of the raft and the development of technic player in the run and rhythm and thus affected Improved the length of the glove step as "the players must exercise more reliance on the visual vision of beating on the glove in a wide step with no less or less loss of jogging speed." (Awad Al-Mayah,2008) This also supports the results from previous literature that exercise can increase enemy speed (Meylan\&Malatesta,2009).

The approximate running time and the time of the three steps were significant and the researcher attributed the reason for the rush to the performance of special exercises that enable the player to control the speed of his body, which is related to the time of jogging "The more horizontal speed the lower the time the greater the payment process and the production of speed and great launch power(Atiković,2012), Acceleration of horizontal velocity and kinetic energy and thus less performance time "(Abdel Kareem,2005), Highlighting the enhancement of force production is most likely by improving the time to start muscular transformation and the ability to recruit specific muscle fibres, most notably Type 2 . However, the results contrast with Ahmet et al. (Ahmet et al,2013). Who did not find a difference in running time after exercise? The current study adds to the current literature that jogging can be increased through exercise, however, it is not possible to distinguish between stage 18, which is often affected. In addition, the increase in jogging speed and the distance from elevation to the distance of the board, which were all positively enhanced to a "moderate" level, can be attributed to an improvement in the workout shortening cycle. Decentralized contraction during bending plantar bending and the effectiveness of lap flexion of bending and torsion in gastrocnemius and quadriceps muscles (Chimera et al,2004), (Ball\&Scurr,2009). The concentric contractions are followed immediately, allowing the flexible component of the chain to enhance the production of the force (Bobbert et al,1996).

As for the angle of starting the body and the angle of advancement was significant, the researcher attributed the exercises that were used of a skilled nature and development of the payment process at the moment of 
advancement and see Nizar student that "the highest altitude reaches the body after the departure depends largely on the angle of launch and speed.

Increasing the angle of advancement increases the starting angle depending on their ability and ability to convert the largest amount of energy to the vehicle closest to the vertical velocity and get a very slight rise of the performance of the Arab horde "that is, the closer the angle of the body's tendency to run to the nearest level of the vertical, Body which is less resistant to body weight "(Sharm,1995).

The improvement of this angle is related to the result of variation in the distance between the vertical between the force of the ground and the centre of gravity and mutual influence outside the centre of gravity at the moment of elevation in the sense that the angle of departure affected by the angle of advancement and this is confirmed by Shehata, "the lower the angle of advancement, It will affect the increase in the movement of horizontal speed at the expense of the vertical and thus increase the capacity of horizontal motor, i.e. the launch of the body will be close to horizontal (altaleb,1982).

The technical performance was significant and attributed to the researcher is the result of training exercises for the sample and according to the variables (Foot Scan) and the kinetic have The technical performance was significant and attributed to the researcher is the result of training exercises for the sample and according to the variables (Foot Scan) and the kinetic have clearly affected the level of performance of the player because of the physical qualities that helped the player to increase speed and led to the driving force of the man when the player based on the glove In total, the player gave sufficient strength to the required movements in the air and these movements did not come as a result of this speed only, but as a result of the development of fitness qualities and reactions that developed as a result of exercise(Shehata,1989).

\section{CONCLUSIONS}

1. Improvement of the relationship and improvement of the relationship positively affect the improvement of performance.

2. The effectiveness of the exercises developed within the training curriculum in the improvement of the exercise and the progress on the indices (Foot Scan) and kinetic in performance Round off Back tuck (Tsukahara) on the jumping platform.

3. Workouts to reduce the deviation of the foot from the real path of running convergence, which helped the economy time and effort and reduce distance.

4. Exercises used in tools and means of assistance in accordance with the skill performance within the training of special strength and speed, helped him to improve the strength and pressure Almtlat moment of rapprochement and upgrading.

\section{REFERENCES}

Mohammed Shehata.(1992).Gymnastics in skill analysis, Knowledge House, Alexandria, p.43.

Ford, P., De Ste Croix, M., Lloyd, R., Meyers, R., Moosavi, M., Oliver, J., ... \& Williams, C. (2011). The long-term athlete development model: Physiological evidence and application. Journal of sports sciences, 29(4), 389-402. https://doi.org/10.1080/02640414.2010.536849

Bencke, J., Damsgaard, R., Sækmose, A., Jørgensen, P., Jørgensen, K., \& Klausen, K. (2002). Anaerobic power and muscle strength characteristics of 11 years old elite and non-elite boys and girls from gymnastics, team handball, tennis and swimming. Scandinavian journal of medicine \& science in sports, 12(3), 171-178. https://doi.org/10.1034//.1600-0838.2002.01128.x 
Sands, A., Friemel, F., Stone, M. H., \& Cooke, C. B. (2006). Any effect of gymnastics training on upperbody and lower-body aerobic and power components in national and international male gymnasts?. Journal of strength and Conditioning Research, 20(4), 899-907. https://doi.org/10.1519/00124278200611000-00029

Bradshaw, E. J., \& Rossignol, P. L. (2004). Gymnastics: Anthropometric and biomechanical field measures of floor and vault ability in 8 to 14 year old talent-selected Gymnasts. Sports Biomechanics, 3(2), 249-262. https://doi.org/10.1080/14763140408522844

Bradshaw, E., Thomas, K., Moresi, M., Greene, D., Braybon, W., McGillivray, K., \& Andrew, K. (2014). Biomechanical field test observations of gymnasts entering puberty.

Bale, P., \& Goodway, J. (1990). Performance variables associated with the competitive gymnast. Sports Medicine, 10(3), 139-145. https://doi.org/10.2165/00007256-199010030-00001

Kums, T., Ereline, J., Gapeyeva, H., \& Paasuke, M. (2005). Vertical jumping performance in young rhythmic gymnasts. Biology of sport, 22(3), 237.

Atiković, A. (2012). New regression models to evaluate the relationship between biomechanics of gymnastic vault and initial vault difficulty values. Journal of human kinetics, 35(1), 119-126. https://doi.org/10.2478/v10078-012-0085-6

Essam El-Din Abd al-Khaliq.(2005). sports training theories and applications, i 1, facility knowledge, Alexandria.

Dinyman, G.B. \&Etal.(1998). Sports speed, 2add. Champin, lily human Kinetics. USA.

Saeb Attia al-Obeidi and others.(1991). biomechanics applied, Mosul, Book House Printing and Publishing.

Kurz, T. (2001). Science of sports training: how to plan and control training for peak performance. Stadion.

Muslim BadrAwad Al-Mayah, (2008), November, Jumping Mechanics in the Gymnastics, a lecture published in the Iraqi Sports Academy.

Meylan, C., \& Malatesta, D. (2009). Effects of in-season plyometric training within soccer practice on explosive actions of young players. The Journal of Strength \& Conditioning Research, 23(9), 26052613. https://doi.org/10.1519/jsc.0b013e3181b1f330

Serih Abdel Kareem.(2005). Advanced Studies in Biomechanics, Amman house thought for publication, p 85.

Alptekin, A., Kılıç, Ö., \& Maviş, M. (2013). The effect of an 8-week plyometric training program on sprint and jumping performance. Serbian Journal of Sports Sciences, 7(2).

Ball, N. B., \& Scurr, J. C. (2009). Bilateral neuromuscular and force differences during a plyometric task. The Journal of Strength \& Conditioning Research, 23(5), 1433-1441. https://doi.org/10.1519/jsc.0b013e3181a4e97f

Chimera, N. J., Swanik, K. A., Swanik, C. B., \& Straub, S. J. (2004). Effects of plyometric training on muscle-activation strategies and performance in female athletes. Journal of athletic training, 39(1), 24.

Bobbert, M. F., Gerritsen, K. G., Litjens, M. C., \& Van Soest, A. J. (1996). Why is countermovement jump height greater than squat jump height?. Medicine and science in sports and exercise, 28, 1402-1412. https://doi.org/10.1097/00005768-199611000-00009

Nizar altaleb.(1982). Motion Analysis, Baghdad: Baghdad University printing, p10.

Sharm,(1995). Speed, take off - Hand - push off abilities in gymnastics Vaulting, A biomechanical study, Nis scientific journal (Patiala), p190.

Mohamed Ibrahim Shehata.(1989). guidebook of floor exersice Gymnastics and vault table, Alexandria, The Technical Printing and Publishing. 


\section{(c) $(7)(\mathrm{F}$}

This work is licensed under a Attribution-NonCommercial-NoDerivatives 4.0 International (CC BY-NC-ND 4.0). 